\title{
Statyba
}

\section{STRAIN-STRESS ANALYSIS OF REINFORCED CONCRETE BEAMS STRENGTHENED WITHOUT UNLOADING BY EXTERIOR REINFORCEMENT}

A. Šneideris \& G. Marčiukaitis MSc (Eng)

To cite this article: A. Šneideris \& G. Marčiukaitis MSc (Eng) (2000) STRAIN-STRESS ANALYSIS OF REINFORCED CONCRETE BEAMS STRENGTHENED WITHOUT UNLOADING BY EXTERIOR REINFORCEMENT, Statyba, 6:5, 307-314, DOI: 10.1080/13921525.2000.10531607

To link to this article: https://doi.org/10.1080/13921525.2000.10531607

Published online: 26 Jul 2012.

Submit your article to this journal ๘

Џ Article views: 48 


\section{APKRAUTU GELŽBETONINIU SIJŲ, STIPRINAMŲ PAPILDOMA ARMATŨRA, ITEMPIUQ-DEFORMACIJŲ BŪVIO ANALIZE்}

\section{A. Šneideris, G. Marčiukaitis \\ Vilniaus Gedimino technikos universitetas}

\section{Ivadas}

Teisingas gelžbetoninių konstrukcijų būvio jvertinimas eksploatacijos laikotarpiu ir visų pirma itempių-deformacijų būvio įvertinimas yra svarbus bendram eksploatuojamos konstrukcijos būklès ivvertinimui, ypač kai konstrukcija stiprinama.

Konstrukcinès statybinès medžiagos, tokios kaip betonas, armatūra ir pan., apkrautos deformuojasi skirtingai. Šis konstrukcijų deformavimasis vyksta skirtingai, sukeldamas ivairios formos ir dydžio ịtempių būvị [1, 2]. Yra daug veiksniu, kurie lemia lenkiamuju gelžbetoninių elementų itempių ir deformaciju būvị. Iki tam tikros ribos šis būvis kinta ir, esant linijiniam valkšnumui, jo kitimas stabilizuojasi. Pasikeitus salygoms jis gali keistis: itempiai ir deformacijos betone ir armatūroje gali padideti arba šiek tiek sumažèti. Didžiausią būvio pasikeitimą, kai konstrukcija nepažeista, sukelia įvairiụ poveikių (apkrovu, temperatūros ir pan.) pokyčiai.

Dažniausiai konstrukcijos stiprinamos papildoma armatūra. Dèl to turi būti nustatyta, kaip panaudojama jụ tempiamojoje zonoje esanti armatūra ir likęs jos laikomosios galios resursas. Skaičiavimais vertinant šią armatūrą būtina atsižvelgti ì tai, kokią ittempių ir deformaciju būvio stadiją ji jau yra pasiekusi.

Nežinant faktinių betono ir armatūros įtempių, negalima tiksliai ivertinti betono ir tempiamosios armatūros laikomosios galios resurso (likučio).

Tarp skirtingos stadijos armatūru vyksta ịtempių persiskirstymas, turintis itakos stiprinamų konstrukciju laikomajai galiai ir ju ilinkiams.

Norint skaičiavimu ivertinti šių įtempių persiskirstymą ir nustatyti racionaliausią abiejų armatūrų panaudojima, būtina žinoti armatūros itempiụ ir deformacijụ analitines išraiškas. Be to, $\sigma(\varepsilon)$ priklausomybes reikia žinoti, norint ivertinti visụ stadijų konstrukcijụ bũvị, iskaitant ir suirimą. Ypač tai svarbu nustatant irąžu persiskirstymą statiškai nesprendžiamose konstrukcijose.

Projektavimo normose (SNirT) nurodyta, kad lenkiamujų gelžbetoninių elementų, kai jie apkrauti apkrova, didesne kaip 65\% nuo skaičiuojamosios, normaliniu pjūviụ laikymo galia mažèja. Tokio mažèjimo pagrissto ivertinimo nėra, nes nežinoma, kaip ivertinti esamos ir stiprinant papildomai pridetos armatūru itempius ir deformacijas, ju tarpusavio persiskirstymą.

Yra pasiūlyta ivairių konstrukcijų stiprinimo ir skaičiavimo būdu [3-7], tačiau tokie skaičiavimai sudètingi ir jais neivertinamos stiprinamų konstrukcijų medžiagu plastinès deformacijos.

Iki šiol konstrukcijos, sustiprintos iš anksto Łtemptomis templèmis arba papildoma neitemptaja armatūra, skaičiuojamos taikant formules kaip paprastoms gelžbetoninèms konstrukcijoms skaičiuoti, neatsižvelgiant $\mathfrak{i}$ armatūros ịtempių ir deformacijų būvị virš takumo ribos. Mūsų atlikta analizė rodo, kad stiprinimo metodui parinkti ir skaičiavimo tikslumui labai svarbūs yra įtempiai konstrukcijos armatūroje (ypač kritiniu atveju, kai jie viršija takumo ribą), papildomos armatūros panaudojimas ir irąžu persiskirstymas tarp šių armatūrú.

Tačiau tyrimų šiais klausimais beveik nèra. Todẻl šio straipsnio tikslas - pasiūlytỉ apkrautų gelžbetoniniu sijų, sustiprintų papildoma armatūra, stiprumo skaičiavimo metodą įvertinant pradinị armatūros ịtempių-deformacijų būvị ir eksperimentiškai patikrinti, kokią itaką sustiprintos konstrukcijos darbui turi elemente esančios armatūros laikomosios galios resursas.

\section{Teorinès prielaidos ir analizè}

Gelžbetoninių sijų, sustiprintụ papildoma armatūra, pridèta išoreje, stiprumas normaliniame pjūvyje apskai- 
čiuojamas kaip ir paprastojo gelžbetoninio elemento iš pusiausvyros lygčių apie tempiamosios armatūros svorio centrą $[3,6]$.

Normalinio pjūvio stiprumas apskaičiuojamas iš pusiausvyros lygties apie ekvivalentinio skerspjūvio gniuždomosios zonos centrą:

$$
\begin{gathered}
M_{u}=R_{s} A_{s, \text { red }}\left(h_{0, \text { red }}-0,5 x\right)+R_{s c} A_{s}^{\prime}\left(h_{0, \text { red }}-a_{s}^{\prime}\right), \\
x=\frac{R_{s} A_{s, r e d}-R_{s c} A_{s}^{\prime}}{R_{b} b}, \\
A_{s, r e d}=A_{s}+A_{s s} \frac{R_{s s}}{R_{s}}, \\
h_{0, \text { red }}=h_{0}+\frac{R_{s s} A_{s s}}{R_{s} A_{s, r e d}}\left(h_{0, s}-h_{0}\right) .
\end{gathered}
$$

$A_{s}^{\prime}, A_{s}$ ir $A_{s s}$ - gniuždomosios, tempiamosios ir papildomos armatūros plotai; $R_{b}$ - gniuždomojo betono stipris; $R_{s c}, R_{s}, R_{s s}$ - gniuždomosios, tempiamosios ir papildomos armatūros skaičiuojamasis stipris; $h_{0, s}$, $h_{0}$ - atstumai nuo gniuždomosios zonos viršaus iki papildomos armatūros skerspjūvio vidurio ir tempiamosios armatūros skerspjūvio vidurio; $M_{u}$ - ribinis lenkimo momentas.

Sijos kreivio apskaičiavimas atliekamas pagal SNirT, kaip paprastam gelžbetoniniam elementui su plyšiais:

$$
\frac{1}{r}=\frac{M}{h_{0 s} z}\left[\frac{\psi_{s}}{E_{s} A_{s}}+\frac{\psi_{b}}{\left(\varphi_{f}+\xi\right) b h_{0 s} E_{b} v}\right] .
$$

Visi dydžiai, jeinantys ị (5) formulę, apskaičiuoja$\mathrm{mi}$ ir parenkami remiantis SNirT, atsižvelgiant $i$ sustiprintos sijos skerspjūvi. Koeficientas $\psi_{S}$ gali būti skaičiuojamas pagal SNirT (167) formulę. Tačiau sijoms, kurios iki stiprinimo jau buvo supleišèjusios, šł koeficientą patariama imti lygu 1 , nes dalis skaičiavimais vertinamos armatūros jau neturi jokio sukibimo su betonu.

Jei lenkiamasis gelžbetoninis elementas, stiprinamas papildoma armatūra, dirbo plastinejje stadijoje, tai šis skaičiavimas duoda dideles paklaidas, nes neteisingai ivertina įrąžu persiskirstymą ir elemente esančios armatūros galios resurso likuti. Mūsų tyrimai rodo, kad naudojantis (1) lygtimi pirmajame jos naryje reikia taikyti ne armatūros stiprumą $R_{s}$, o sumini armatūros itempi $\sigma_{s, r e d}$, kuris jvertintu tiek plastini elemente esančios armatūros darbą, tiek ir tampru papildomai pridetos neitemptosios armatūros darbą. Taikant kompozitu teorijos „mišinio dèsnị“ $[8,9]$, galima juertinti bendrą armatūrų, kurių viena dirba tampriojoje, o kita - plastinèje stadijose, darbą. Taigi:

$$
\begin{gathered}
\sigma_{s, r e d}=V_{1} \sigma_{s}+V_{2} \sigma_{s s}, \\
V_{1}+V_{2}=1,
\end{gathered}
$$

$V_{1}$ ir $V_{2}$ - elemente esančios ir papildomai pridètos armatūros santykinés dalys sijoje; $\sigma_{s}$ ir $\sigma_{s s}$ - elemente esančios armatūros ir papildomai pridètos neitemptos armatūros ịtempiai.

Norint vertinti konstrukcijos darbą, pirmiausia reikia atsižvelgti i jos darbą iki stiprinimo. Jei konstrukcija dirbo plastinèje stadijoje, tai jos normalinio pjūvio stiprumas:

$$
\begin{gathered}
M=\sigma_{s, p l} A_{s}\left(h_{0}-0,5 \bar{x}\right)+R_{s c} A_{s}^{\prime}\left(h_{0}-a_{s}^{\prime}\right), \\
\bar{x}=h_{0} \cdot\left(\frac{\varepsilon_{b, R}}{\varepsilon_{b, R}+\varepsilon_{s, u}}\right)
\end{gathered}
$$

$\sigma_{s, p l}$ - plastinès armatūros deformacijos; $\bar{x}$ - gniuždomosios zonos aukštis, kai armatūra dirba plastinèje stadijoje; $\varepsilon_{b, R}$ ir $\varepsilon_{s, u}$ - ribinès gniuždomojo betono ir tempiamosios armatūros deformacijos, imamos iš eksperimentinių kreivių arba pagal mūsụ pasiūlytas analitines išraiškas [10].

Kadangi stiprinimo metu elementas nenukraunamas, tai tolesnis jo stiprumas turi atspindèti (7) lygtimi ivertintą darbo stadiją. Vadinasi, (1) lygti užrašome taip:

$$
\begin{aligned}
& \left(M+M_{s s}\right)=\sigma_{s . r e d} A_{s, r e d}\left(h_{0, r e d}-0,5 \bar{x}\right)+ \\
& +R_{s c} A_{s}^{\prime}\left(h_{0 . r e d}-a_{s}^{\prime}\right)
\end{aligned}
$$

$M_{s s}$ - atlaikymo momentas, ivertinantis papildomą armatūrą.

Ivertinę irąžu persiskirstymą tempiamojoje zonoje pagal (6), (8) lygti użrašome taip:

$$
\begin{gathered}
M_{u}=\left(V_{1} \sigma_{s}+I_{2} \sigma_{s s}\right) A_{s, r e d}\left(h_{0, r e d}-0,5 \bar{x}\right)+ \\
+R_{s c} \cdot A_{s}^{\prime}\left(h_{0, r c d}-a_{s}^{\prime}\right) \\
A_{s, r e d}=A_{s}+A_{s s s} \frac{\sigma_{s s}}{\sigma_{s}}, \\
h_{0, r e d}=h_{0}+\frac{\sigma_{s s} A_{s s}}{\sigma s A_{s, r e d}}\left(h_{0, s}-h_{0}\right)
\end{gathered}
$$




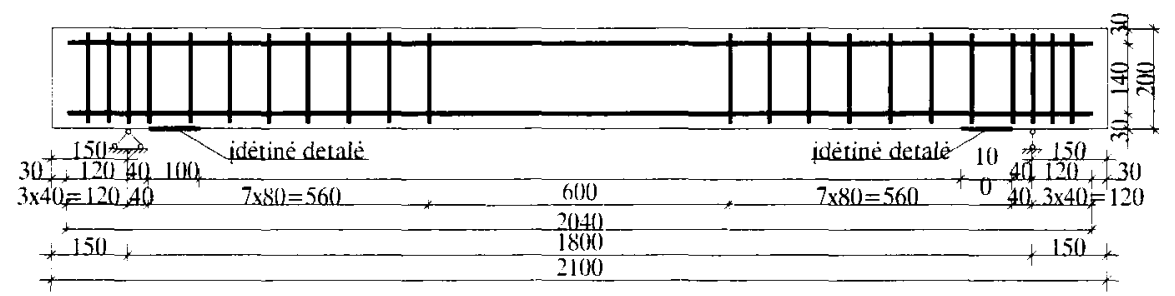

1 pav. Eksperimentui paruoštų sijų konstrukcija

Fig 1. Arrangement of reinforcement in the beams investigated

$$
\bar{x}=h_{0, r e d} \cdot\left(\frac{\varepsilon_{b, R}}{\varepsilon_{b, R}+\varepsilon_{s, u}}\right) .
$$

$A_{s}^{\prime}, A_{s}$ ir $A_{s s}$ - gniuždomosios, tempiamosios ir papildomos armatūros plotai; $R_{s c}$ - gniuždomosios armatūros skaičiuojamasis stipris; $h_{0 . s}, h_{0}-$ atstumai nuo gniuždomosios zonos viršaus iki papildomos armatūros skerspjūvio svorio centro ir tempiamosios armatūros skerspjūvio centro; $M_{u}$ - ribinis lenkimo momentas; $\bar{x}$ - gniuždomosios zonos aukštis, kai sijoje esanti armatūra dirba plastinèje stadijoje.

\section{Eksperimentinių tyrimų metodika}

İražų persiskirstymo sustiprintame elemente ir pradinio ittempių-deformacijų būvio itakos stiprinamos sijos tempiamosios zonos darbui ivertinti buvo atlikti specialūs eksperimentai.

Buvo pagamintos ir išbandytos 8 sijos, kurių konstrukcija parodyta 1 paveiksle. Tempiamoji siju zona armuota $\varnothing 10$ AlII klasès armatūra, kurios $\sigma_{p l}=440$ $\mathrm{MPa}, \sigma_{u}=550 \mathrm{MPa}, E_{s}=1,98 \times 105 \mathrm{MPa}$. Skersine ir gniuždomosios zonos išilginè armatūra Ø6 Al klasès. Sijos vidineje dalyje ties atraminemis zonomis buvo ibetonuotos idètinès detalès, prie kurių vẻliau buvo virinama stiprinančioji armatūra. Tai leido nustatyti elemente esančios armatūros darbą, atsižvelgiant i tai, kad ši armatūra nepažeidžiama privirinus papildomą armatūrą.

Sijos S1-1, S1-2, S2-1, S2-2, S3-1, S3-2 buvo apkrautos ilgalaike apkrova, praejus dviem mènesiams po betonavimo. Viena kontroliné sija $\mathrm{Sl}$ buvo išbandyta trumpalaike apkrova siju apkrovimo ilgalaike apkrova metu, o kita kontrolinė sija S2 sustiprinta ir išbandyta trumpalaike apkrova kartu su kitomis sustiprintomis sijomis.

Ilgalaikiam bandymui sijos buvo apkrautos apkrova, nuo kurios $M \approx 0,65 M_{u}$. Bandiniai apkrauti buvo
80 paru, tada papildomai apkrauti iki $0,85 M_{u}, 0,90 M_{u}$ ir $0,95 M_{u}$ ir sustiprinti.

Betono fizikinèms-mechaninèms savybèms nustatyti kartu su sijomis buvo pagaminta 10 prizmiu $(10 \times 10 \times 40 \mathrm{~cm})$ ir 20 kubeliu $(10 \times 10 \times 10 \mathrm{~cm})$.

Visi bandiniai buvo gaminami iš vienos sudeties betono $-1: 1,63: 2,51$. Vandens cemento santykis $\mathrm{V} / \mathrm{C}=0,45$. Cemento kiekis $1 \mathrm{~m}^{3}$ betono mišinio $\mathrm{C}=430 \mathrm{~kg} / \mathrm{m}^{3}$. Betono mišinio slankumas pagal kūgio nuoslūgi $-6 \mathrm{~cm}$. Naudotas CM 2 M42,5 markès Akmenès portlandcementis. Užpildams buvo naudojamas plautas smélis ir žvyras (frakcija 4/16).

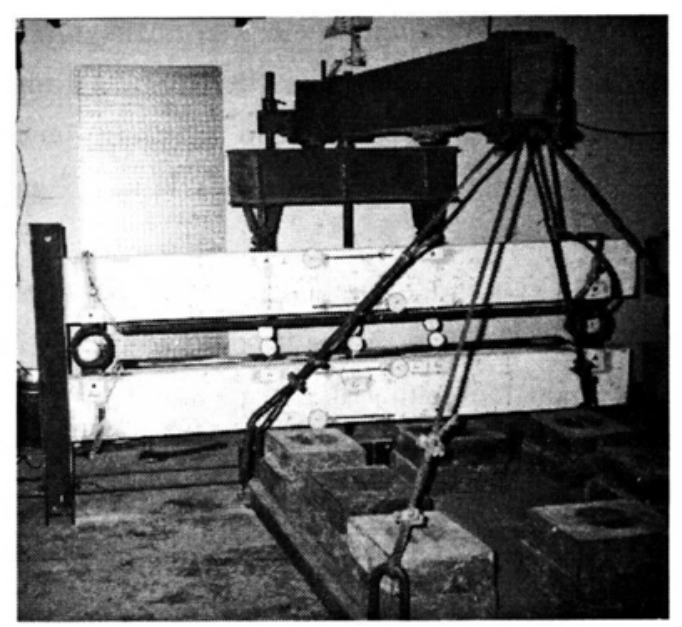

2 pav. Ilgalaikio apkrovimo bandymai

Fig 2. Application of long-term load to the beams investigated

Ilgalaikiai bandymai esant pastovioms apkrovoms buvo atliekami pagal svertinę sistemą, kurios schema: sijos ant dvieju atramu, apkrautu dviem vienodomis jègomis tarpatramių trečdaliuose. Patalpos temperatūra buvo $15-18^{\circ} \mathrm{C}$, o santykiné drégmé $75-80 \%$ (žr. 2 pav.).

Betono ir armatūros deformacijos buvo matuojamos laikrodiniais indikatoriais, kuriụ padala yra $0,001 \mathrm{~mm}$. 
Siju ilinkiai buvo matuojami laikrodiniais indikatoriais, kuriu padala yra $0,01 \mathrm{~mm}$.

\section{Eksperimentinių tyrimų rezultatai ir jų analizè}

Fizikinès-mechaninès medžiagu savybès buvo tiriamos norint gauti duomenis, reikalingus pagrindiniams tyrimo tikslams.

Betono kubinis stiprumas buvo nustatomas bandant $10 \times 10 \times 10 \mathrm{~cm}$ kubelius.

Betono bandymai parode, kad po 140 parų betono stiprumas, palyginti su 28 parų betonu, padidèjo $18 \%$ ir vidutiniškai $5,5 \%$, palyginti su stiprumu siju apkrovimo metu.

Laikoma, kad tamprumo modulis didejja, didèjant betono amžiui. Kai kurie tyrimai [11] rodo, kad, didèjant betono amžiui $(t>50$ paru $)$, pastebimas betono tamprumo modulio mažějimas. Todèl vertinant gelžbetoninių konstrukcijų itempių-deformaciju būvi, yra svarbu turèti duomenų apie tamprumo modulio kitimą priklausomai nuo betono amžiaus.

Pradinis betono tamprumo modulis buvo nustatomas bandant betonines $10 \times 10 \times 40 \mathrm{~cm}$ prizmes.

Mūsu atlikti tyrimai parodè, kad nustatytomis temperatūros ir drégmès sąlygomis betono tamprumo modulis didejo. Tai atitinka daugelio tyrinetojụ gautus rezultatus. Tamprumo modulio kitimas laikui bėgant pateiktas 3 paveiksle.

Ilgalaikiai sijų deformaciju tyrimai iki stiprinimo buvo atlikti su 6 sijomis. Visos jos buvo apkrautos $280 \mathrm{kN}$ jèga grynajam lenkimui. Tai sudaro apie $0,65 M_{u}$. Čia $M_{u}$ - sustiprintu papildoma horizontaliaja armatūra lenkiamuju gelžbetoninių sijų suirimo momentas. Siju ilinkio didèjimas laikui begant pateiktas 4 paveiksle.

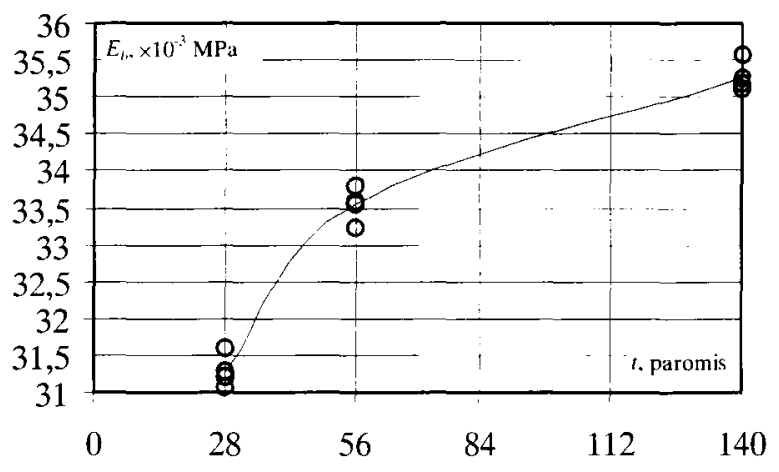

3 pav. Betono tamprumo modulio kitimas

Fig 3. Time-history of concrete elasticity modulus

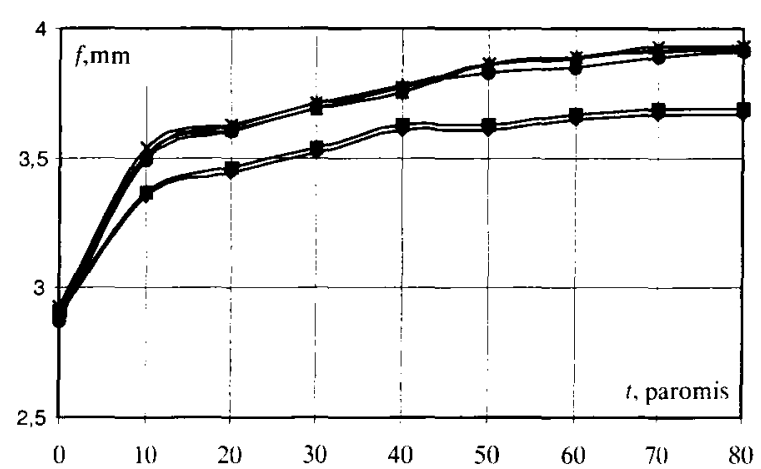

4 pav. Sijų ilinkio didéjimas po ilgalaike apkrova

Fig 4. Time-history of the deflection of the experimental beams exposed to a long-term load

Šiu kreiviu analizė rodo, kad, sijos, nors ir nežymiai, tačiau deformavosi skirtingai (apie $7 \%$ po 80 parų). Tai galima paaiškinti tuo, kad skyrèsi jụ skerspjūvio matmenys (iki $5 \mathrm{~mm}$ ) bei armatūros karkasų padètis, vibravimu tankinant betona.

Sijụ ilinkiai ilgalaikio apkrovimo metu padidejjo $32-37 \%$.

Kaip matyti iš 4 paveikslo, siju ilinkių didejjimas po $50-60$ paru yra nežymus. Tai patvirtina ir betono bei armatūros deformacijų kitimas laikui bègant ( 5 , 6 pav.).

Kaip matyti iš 5 paveikslo, deformacijos gniuždomajame betone labiausiai didejo per pirmasias 40 paru. Per tą laikotarpi jos padidejo apie $56 \%$. Tuo tarpu per likusias 40 paru šis padidéjimas siekè apie $18 \%$. Tačiau po 60 paru jų didejjimas beveik stabilizavosi. Vadinasi, kai $M=0,65 M_{u}$, itempiai sukèlé linijini betono valkšnumą.

Reikia pažymėti, kad beveik nèra duomenų apie armatūros plastines deformacijas ir jụ eigos pobūdi,

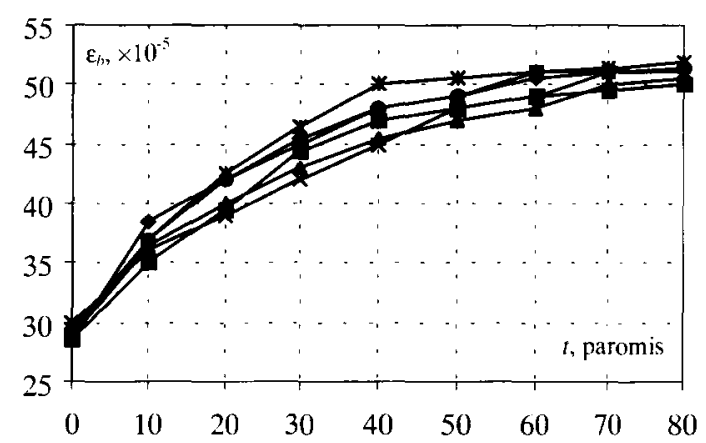

5 pav. Gniuždomosios betono zonos deformacijų kitimas

Fig 5. Time-history of the concrete strain in the compressive zone of beams 


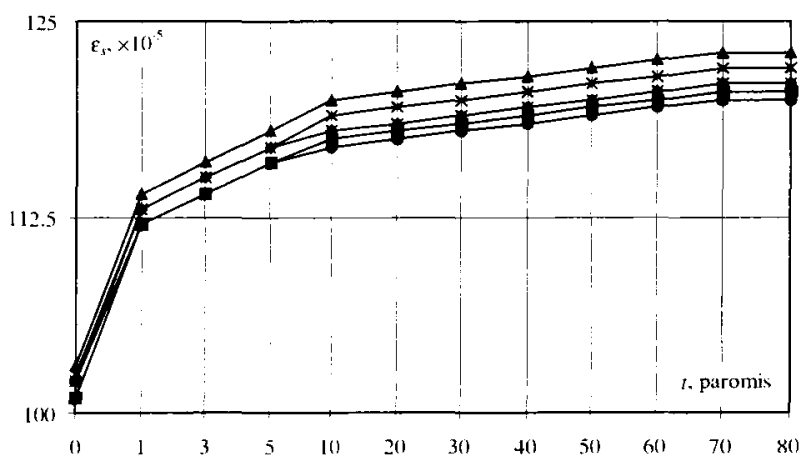

6 pav. Tempiamosios armatūros deformavimasis veikiant ilgalaikei apkrovai

Fig 6. Time-history of the strain in the tensile reinforcement of the experimental beams exposed to a long-term load

veikiant ilgalaikei apkrovai. Mūsų atliktų tyrimų duomenimis (6 pav.), jos labai dideja pirmosiomis dienomis po apkrovimo. Per pirmąsias 10 parų jos padidèjo apie $7 \%$, o bendras padidejimas per 80 paru buvo $\approx 9 \%$.

Nors esant ilgalaikei apkrovai armatūra nebuvo pasiekusi normomis nustatytos takumo ribos, tačiau, kaip rodo mūsų tyrimai [8], prieš takumo ribą $\left(0,7-0,8 \sigma_{0,2}\right)$ pradeda pasireikšti plastinès armatūros deformacijos, kurios, veikiant ilgalaikei apkrovai, tam tikrą laiką dideja ir santykinai greitai (po 10 paru) stabilizuojasi. Tuo galima paaiškinti ir žymų sijų ilinkių didejjimą per pirmąsias 10 paru (4 pav.).

Praèjus 80 paroms sijos buvo papildomai apkrautos trumpalaike apkrova atitinkamai iki $0,85 M_{u}$ (S1-1, S1-2), 0,90 $M_{u}$ (S2-1, S2-2), 0,95 $M_{u}$ (S3-1, S3-2) ir sustiprintos 2010 AIII klasès armatūros strypais.

Kadangi papildoma armatūra buvo virinama prie ¡dètinių detalių, tai virinimo procesas nepakeitè tolesnio jau elemente esančios armatūros deformavimosi.

7 paveikslo kreivių analizè rodo, kad armatūra, jei stiprinimo metu jos ịtempiai viršija takumo ribą, turi itakos siju standumui (ilinkiams) ir laikomajai galiai. Tai galima paaiškinti deformacijų ir įtempiụ armatūrose persiskirstymu, ir tai patvirtina armatūrų deformavimosi pobūdis. Pavyzdžiui, sustiprinus siją esant $M=0,85 M_{u}$ ir pradejus apkrauti, sijoje esanti ankstesnioji armatūra beveik nesideformuoja ir itempius perima papildomai pridèta armatūra.

Tamprumo stadijoje esanti papildoma armatūra perima dali sijoje esančios armatūros plastinių deformaciju. Jụ sąlyginés $\sigma-\varepsilon$ priklausomybès atstojamoji yra tarp jos sudedamuju. Tai parodyta 8 paveiksle.
Jų atstojamoji rodo nedideles plastines armatūros deformacijas.

Kaip matyti iš pateiktu paveikslụ, papildomai pridèta armatūra isitraukè $\mathfrak{i}$ darbą ir padidino sijụ laikomąją galią 6,5-15\% priklausomai nuo apkrovimo lygio iki stiprinimo. Tai galima paaiškinti skirtingu armatūros darbu skirtingose apkrovimo stadijose. Armatūros deformavimosi pobūdis ( 9 pav.) turèjo itakos ne tik laikomajai galiai, bet ir bendram jụ darbo ir irimo mechanizmui.

Daugiausia dèmesio buvo skiriama irąžu persiskirstymui tarp tempiamujų armatūru ištirti. 10 paveiksle

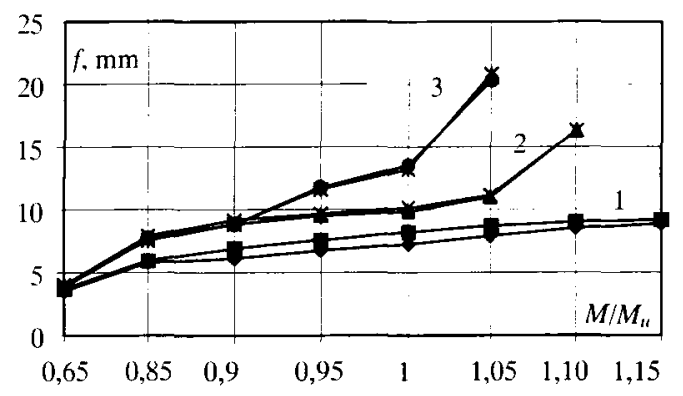

7 pav. Sijos ilinkiai bandant trumpalaike apkrova po sustiprinimo iki suirimo: $1-$ sijos S1-1, S1-2 $\left(0,85 M_{u}\right)$ : 2 - sijos S2-1, S2-2 $\left(0,9 M_{u l}\right): 3$ - sijos S3-1, S3-2 $\left(0,95 M_{u}\right)$

Fig 7. Deflections of the strengthened beams measured up to bending failure during the application of short-term loads: 1 - beams SI-1, SI-2 $\left(0.85 M_{u}\right): 2$ beams S2-1, S2-2 $\left(0.9 M_{u}\right): 3$ - beams S3-1, S3-2 $\left(0.95 M_{u}\right)$

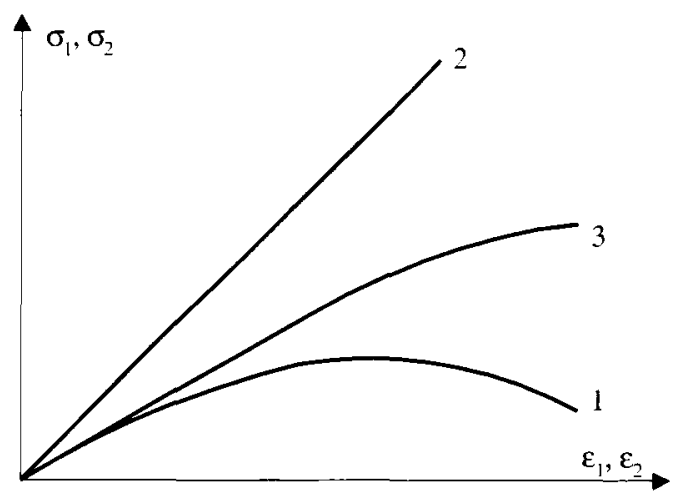

8 pav. Sijoje esančios (1) ir papildomai pridètos (2) armatūros deformacijų priklausomybès ir jų atstojamoji (3)

Fig 8. The stress-strain relationships for the reinforcement cast in concrete (1), for the exterior reinforcement (2) and the reduced reinforcement as given by $\mathrm{Eq}(6)$ (3) 


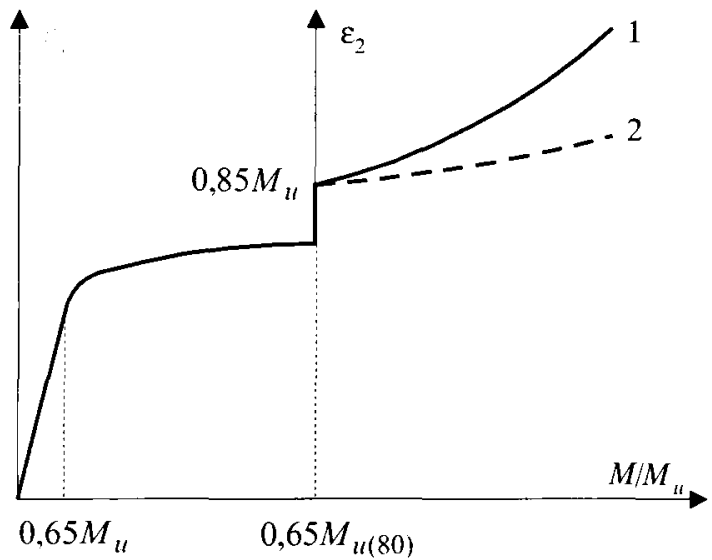

9 pav. Sijoje esančios (1) ir papildomai pridétos (2) armatūros deformaciju priklausomybès viso konstrukcijos darbo metu

Fig 9. Relationships of the strain in the reinforcement cast in concrete (1) and the exterior reinforcement (2) versus the reduced bending stress measured for the entire stress range

pateikiamas bendras tempiamojoje zonoje esančiu armatūrų darbo grafikas.

Atlikti tyrimai parodè (10 pav), kad elemente esančios armatūros deformavimasis priklauso nuo pradinio itempių būvio. Tačiau, jtraukus ị darbą papildomą armatūrą, jụ didèjimas dèl ịrąžų persiskirstymo sulètejjo. Tuo galima paaiškinti kreivių (10 pav.) pobūdžio panašumą po papildomo apkrovimo, t. y. po $M=0,85 M_{u}$
(a), $M=0,9 M_{u}$
(b) ir $M=0,95 M$
(c).

Armatūros darbo analizè rodo, kad elemente esanti plastiškumo stadijoje dirbanti armatūra turi itakos bendram tempiamosios zonos darbui ir kartu laikomajai galiai ir ilinkiams.

Nagrinejjant sijų laikomają galią buvo palyginti teoriniai ir eksperimentiniai rezultatai. Gauti rezultatai pateikiami lentelëje.

Teoriniai tyrimai rodo, kad neịvertinus plastiškumo stadijoje dirbančios armatūros negalima tiksliai ivertinti bendro sustiprintos konstrukcijos darbo ir jos stiprumo atsargos. Atlikti skaičiavimai (žr. lentelę) ir jų palyginimas su mūsu gautais eksperimentais rodo, kad, konstrukcijai dirbant plastinejje stadijoje, esama skaičiavimo metodika $[3,6]$ neteisingai įvertina likutini armatūros stiprị ir todèl gaunamas didesnis bendras stiprumas, viršijantis bandymo rezultatus. Taikant mūsų pasiūlytą metodiką gaunama 1-2\% atsarga, o pagal esamą metodiką siju laikomoji galia net iki $11 \%$ viršija a)

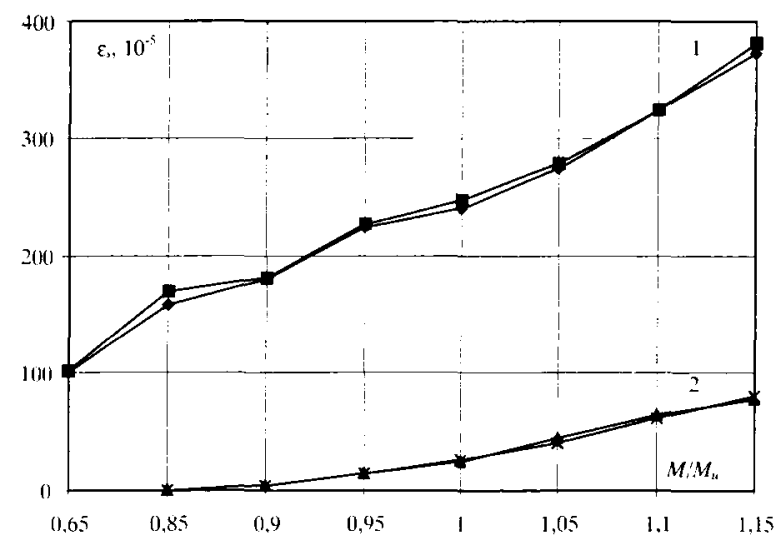

b)

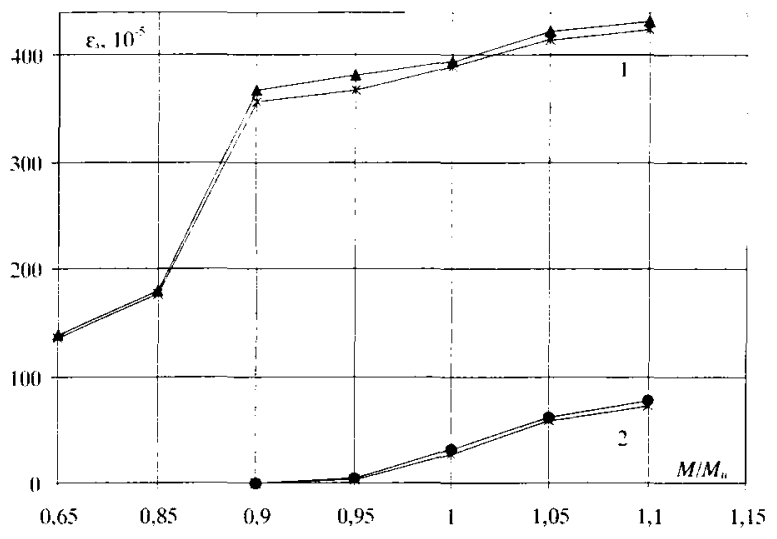

c)

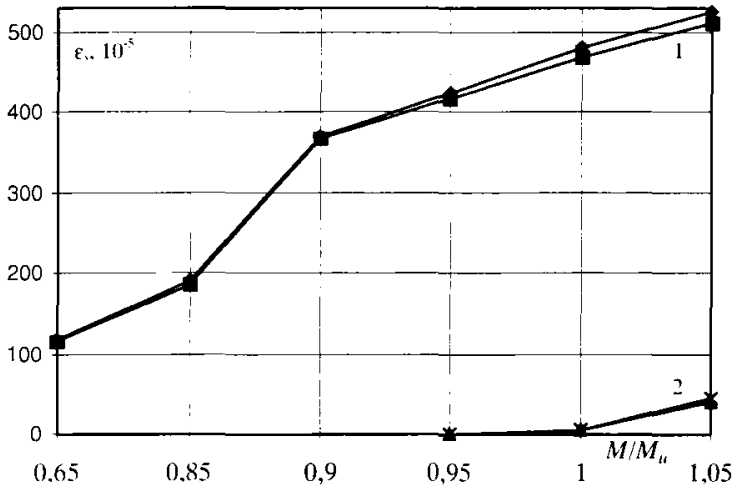

10 pav. Elemente esančios (1) ir papildomai pridetos (2) armatūros itempiai po sustiprinimo nuo trumpalaikès apkrovos sijose S1-1,2 $\left(0,85 M_{u}\right)(\mathrm{a}), \mathrm{S} 2-1,2\left(0,9 M_{u}\right)$ (b), S3-1,2 $\left(0,95 M_{u}\right)$ (c)

Fig 10. Relationships of the strain in the reinforcement cast in concrete (1) and the exterior reinforcement (2) versus the reduced bending stress measured during the application of short-term loads after strengthening: beams S1-1,2 $\left(0.85 M_{u}\right)$ (a), beams S2-1,2 $\left(0.9 M_{u}\right.$ (b), beams S3-1,2 $\left(0.95 M_{u}\right)$ (c) 
eksperimentinius duomenis. Vadinasi, normų pasiūlyta metodika neleidžia teisingai ịvertinti konstrukcijos darbo ir gali sukelti neprognozuojamą suirimą.

\section{Eksperimentiniai ir skaičiuojamieji ribiniai sijų momentai}

Experimental and theoretical bending capacities of the beams investigated

\begin{tabular}{|c|c|c|c|c|}
\hline \multirow{2}{*}{ Sijos } & \multicolumn{4}{|c|}{ Suirimo momentai } \\
\cline { 2 - 5 } & $\begin{array}{c}M_{u, \text { ohs }} \\
(\mathrm{kNm})\end{array}$ & $\begin{array}{c}M_{u, c \text { cal }}(9) \\
(\mathrm{kNm})\end{array}$ & $\begin{array}{c}M_{\text {uccal }}(1) \\
(\mathrm{kNm})\end{array}$ & $\begin{array}{c}M_{\text {u.cuu }} / M_{\text {u..obs }} \\
(9) /(1)\end{array}$ \\
\hline S1-1 & 16,5 & 16,3 & 16,6 & $0,99 / 1,00$ \\
\hline S1-2 & 16,5 & 16,3 & 16,6 & $0,99 / 1,00$ \\
\hline S2-1 & 15,7 & 15,4 & 16,6 & $0,98 / 1,06$ \\
\hline S2-2 & 15,7 & 15,4 & 16,6 & $0,98 / 1,06$ \\
\hline S3-1 & 15,0 & 14,7 & 16,6 & $0,98 / 1,11$ \\
\hline S3-2 & 15,0 & 14,7 & 16,6 & $0,98 / 1,11$ \\
\hline
\end{tabular}

\section{Išvados}

1. Iki šiol taikoma apkrautu gelžbetoniniụ siju stiprumo skaičiavimo metodika ((1) formulè) ne visai ivertina esamos armatūros, dirbančios plastinejje stadijoje, itaką bendram sustiprintų sijų darbui.

2. Teoriniai ir eksperimentiniai tyrimai parodè, $\mathrm{kad}$ tarp esamos ir papildomai stiprinimui pridetos armatūros vyksta itempių persiskirstymas, turintis itakos tempiamosios zonos bendram darbui.

3. Eksperimentiniu tyrimy rezultatai parode ( 10 pav.), kad po sustiprinimo abi armatūros deformuojasi beveik vienodai, neatsižvelgiant i deformaciju lygi stiprinimo metu.

4. Tyrimų rezultatai patvirtino teorines prielaidas, kad, apskaičiuojant apkrautų siju stiprinimą papildoma tempiamaja armatūra, reikia naudotis redukuotais itempiais armatūroje ((6) - (9) formulès), o ne atskirụ armatūru stipriais.

5. Teoriniai rezultatai, apskaičiuoti pagal esamą ir siūlomą metodikas, palyginus su eksperimentais parodè, kad pirmuoju atveju teoriniai rezultatai iki $11 \%$ viršija praktines reikšmes, o pagal mūsų pasiūlytą skaičiavimo metodiką yra tik $2 \%$ mažesni ir leidžia tiksliau ivertinti tempiamosios zonos darbą.

6. Tyrimo rezultatai gali būti naudojami ir analjzuojant irąžu persiskirstymą statiškai nesprendžiamose konstrukcijose.

\section{Literatūra}

1. A. Šneideris. Stiprinamų lenkiamuju gelžbetoniniu konstrukcijų pradinio itempimų-deformaciju būvio teorinio jvertinimo prielaidos // Pirmosios respublikinès jaunuju mokslininku konferencijos „Lietuva be mokslo - Lietuva be ateities", ivykusios Vilniuje $19980930-1002$, medžiaga. 1 t. Technologijos mokslai. V.: Technika, 1998, p. $165-171$.

2. G. Marčiukaitis, A. Šneideris. Eksploatuojamu lenkiamujų gelžbetoniniu konstrukcijụ itempiu-deformacijų būvio ivertinimo metodu parinkimo klausimu // Statybinès konstrukcijos: kūrimas ir stiprinimas: Konferencijos, ivykusios Vilniuje $1998 \mathrm{~m}$. lapkričio $20 \mathrm{~d}$., pranešimų medžiaga. V.: Technika, 1998, p. 43-47.

3. Z. Kamaitis, V. Jokūbaitis. Gelžbetoninių ir mūrinių konstrukciju atstatymas ir stiprinimas: Mokomoji knygelè. Vilnius: Technika, 1986. 92 p.

4. Д. Н. Лазовский. Теория расчета и конструирование железобетонных конструкций эксплуатируемых строительных сооружений: Автореф. дис. ... д-ра техн. наук. Минск, 1998. $41 \mathrm{c}$.

5. Н. М. Онуфриев. Усиление железобетонных конструкций промышленных зданий и сооружений. Ленинград, 1965. 342 c.

6. Е. Р. Хило, Б. С. Попович. Усиление железобетонных конструкций с изменением расчетной схемы и напряженного состояния. Львов: Вища школа, 1976. 146 с.

7. В. А. Клевцов, Е. Г. Кремнева. Расчет прочности нормальных сечений изгибаемых железобетонных элементов, усиленных под нагрузкой // Изв. вузов. Строительство, 1997, № 9. с. 45-49.

8. Ю. В. Немировский, Б. С. Резников. Упруго-пластический изгиб балок из двухкомпонентных материалов // Проблемы прочности, 1972, № 10, с. 11-18.

9. G. Marčiukaitis. Statybinių kompozitu kūrimo ir savybiu prognozavimo principai. V.: Technika, 1998. $134 \mathrm{p}$.

10. G. Marčiukaitis, A. Šneideris. Tempiamosios armatūros $\sigma(\varepsilon)$ priklausomybès virš takumo ribos nustatymas // Statyba, V tomas, Nr. 4. V.: Technika, 1999, p. 237-244.

11. Е. А. Чистяков. О модуле упругости бетона при сжатии // Особенности деформаций бетона и железобетона и использование ЭВМ для оценки их влияния на поведение конструкций. Москва: Стройиздат, 1969. c. $110-117$.

Iteikta 20000924

\section{STRAIN-STRESS ANALYSIS OF REINFORCED CONCRETE BEAMS STRENGTHENED WITHOUT UNLOADING BY EXTERIOR REINFORCEMENT}

\section{A. Šneideris, G. Marčiukaitis}

Summary

The mostly used method for strengthening flexural concrete members is mounting exterior reinforcing bars. When applying the strengthening by exterior reinforcing, the 
problem of assessing the remaining carrying capacity of the member being strengthened and estimating the actual stress in the reinforcement placed in the tensile zone of the member is to be solved.

In the paper a method for the analysis of the flexural concrete members strengthened by exterior reinforcing bars is proposed. The method allows to design the exterior reinforcement by taking account of the remaining carrying capacity of the member being strengthened. Moreover, the method proposed enables one to assess a redistribution of stress between the originally placed reinforcement and the exterior reinforcement used to strengthen the member.

The redistribution of stress has a considerable influence on the carrying capacity of the member as well as on its bending stiffness. The stress-strain relationships of the both reinforcements are necessary for assessing the redistribution of stress between them, and these relationships are input for the analysis method proposed in this paper.

In opposite to other methods suggested in the literature and used for the analysis of the flexural members strengthened in the way described above, the method proposed in the present paper allows one to take account of the pastiche deformations of concrete and steel in the member being strengthened. In addition, the proposed method is less complicated to apply when compared to methods suggested to date.

The method proposed is represented by the formula (9). which expresses the bending capacity of the flexural member after its strengthening. The main idea of the proposed method is to replace the design strengths of the reinforcement cast in concrete and mounted outside the member, $R_{s}$, by the reduced strength $\sigma_{s, r e d}$ which is assigned to the both reinforcements. The reduced strength $\sigma_{s, \text { red }}$ was introduced in order to take account of the plastic deformations of reinforcing steel.

The proposed method was verified by a series of experiments with simple reinforced concrete beams. The aim of the experiments was an investigation of the redistribution of stress inside the normal section of the member analysed and the assessment of the influence of the stress-strain state in the member before strengthening on the characteristics of its tensile zone after the member is strengthened. The results of the experiments are shown in Fig 7. In this figure, the experimental relationship between the deflection of the beams being investigated, $f$, and the reduced bending stress $M / M_{u}$ is depicted, where $M$ is the stress applied and $M_{u}$ is the carrying capacity of the beam. One can see from the polygons shown in Fig 7 that the exceedance of the yield stress in the reinforcement cast in concrete has a considerable influence on the carrying capacity and the bending stiffness of the beams under investigation.

Another results obtained from the experiments with the beams strengthened by the exterior reinforcement is shown in Fig 10. This figure demonstrates the dependence of the strain in the reinforcement cast in concrete and the exterior reinforcement, $\varepsilon$, on the reduced bending stress $M / M_{u}$. From Fig 10, one can conclude that the strain in both reinforcements is influenced by the stress-strain state available in the member before strengthening.

In Table 1, the bending capacities measured in the experiments just mentioned are compared with the ones calculated by applying the formula (9), which utilises the reduced strength $\sigma_{s, r e d}$, and also the formula (1), which expresses the bending capacity through the design strengths $R_{s}$. The formula (1) represents one of the methods suggested to date for the prediction of the bending carrying after strengthening of flexural members by exterior reinforcement. The comparison of the experimental results with the ones obtained from formulas (1) and (9) demonstrates that the method represented by the formula (1) has the unconservative difference in bending capacity of $11 \%$, whereas the proposed method represented by the formula (9) yields a conservative difference of only $2 \%$. The results of experiments may be applied to predict the redistribution of stress in the statically indetermined structures.

Gediminas MARČIUKAITIS. Professor, Doctor Habil. Head of Dept of Reinforced Concrete and Masonry Structures. Vilnius Gediminas Technical University (VGTU), Saulètekio al. 11, LT-2040 Vilnius, Lithuania. E-mail: gelz $(a$ st.vtu.It

A graduate of Civil Engineering Faculty of Kaunas Polytechnic Institute (1957). PhD (1963). Research visit to the University of Illinois (1969). Doctor Habil (1980, Moscow Civil Engineering Institute). Professor (1982). Author and co-author of 5 monographs, 4 text-books and about 300 scientific articles. Research interests: mechanics of reinforced concrete, masonry and layered structures, new composite materials, structures and investigation and renovation of buildings.

Arnoldas ŠNEIDERIS. MSc (Eng). Vilnius Gediminas Technical University (VGTU), Saulètekio al. 11, LT-2040 Vilnius, Lithuania. E-mail: gelz@st.vtu.lt

A graduate of Vilnius Technical University (1993, civil engineer). MSc (1995). PhD student, Dept of Reinforced Concrete and Masonry Structures, VGTU. Research interests: mechanics of reinforced concrete, strengthening of structures. 